$\begin{array}{rr}\text { JURNAL } & \text { Volume } 11, \text { Nomor 4, Agustus } 2015 \\ \text { FIT(1)PATOLOGI } & \text { Halaman } 137-141 \\ \text { I N D O NES I A } & \text { DOI: } 10.14692 / \text { jfi.11.4.137 } \\ \text { ISSN: } 0215-7950 & \end{array}$

KOMUNIKASI SINGKAT

\title{
Ekspresi Rekombinan Gen Protein Selubung Pepper vein yellows virus
}

\author{
Expression of Recombinant Pepper vein yellow virus \\ Coat Protein Gene
}

\author{
Rita Kurnia Apindiati, Gede Suastika*, Kikin Hamzah Mutaqin \\ Institut Pertanian Bogor, Bogor 16680
}

\begin{abstract}
ABSTRAK
Pepper vein yellows virus (PeVYV) isolat Bali telah berhasil diidentifikasi dari tanaman cabai bergejala klorosis. Oleh karena belum tersedia antiserum spesifik PeVYV komersial, untuk kepentingan deteksi perlu upaya membuat antiserum. Salah satu teknik terbaru dalam menyediakan sumber antigen untuk pembuatan antiserum ialah melalui teknik ekspresi gen protein selubung virus pada bakteri ekspresi yang sesuai. Gen protein selubung PeVYV berukuran $\sim 650 \mathrm{pb}$ diamplifikasi dengan primer spesifik, dikloning pada vektor ekspresi pQE30, ditransformasi dan dikayakan ekspresi gen tersebut (overexpression) pada bakteri ekspresi E. coli galur M15 [pREP4]. Analisis SDS-PAGE menunjukkan rekombinan gen protein selubung PeVYV berhasil terekspresi dengan pita protein berukuran $\sim 25 \mathrm{kDa}$ setelah 6 jam diinduksi dengan $0.5 \mathrm{mM}$ IPTG pada suhu $37^{\circ} \mathrm{C}$.
\end{abstract}

Kata kunci: antiserum,rekombinan, SDS-PAGE, vektor ekspresi

\begin{abstract}
Pepper vein yellows virus (PeVYV) isolate from Bali have been identified from pepper plants with chlorosis symptoms. Specific antiserum of PeVYV had not available yet commercially. One of the advance techniques in providing a source of abundant antigen for antiserum production is through molecular approach by overexpressed the coat protein gene in suitable bacterial expression system. PeVYV coat protein gene of $\sim 650 \mathrm{bp}$ in size was amplified using specific primers, then was cloned into pQE30 expression vector and was over expressed in E. coli strain M15 [pREP4]. SDS-PAGE analysis showed that the recombinant coat protein gene of PeVYV was successfully expressed protein band with size of $\sim 25 \mathrm{kDa}$ at 6 hours after induction by $0.5 \mathrm{mM} \mathrm{IPTG}$ on $37^{\circ} \mathrm{C}$.
\end{abstract}

Key words: antiserum, expression vector, recombinant, SDS-PAGE

Pepper vein yellows virus (PeVYV- cabai di Desa Kertha, Kecamatan Payangan, Luteoviridae; Polerovirus) dilaporkan sebagai Kabupaten Gianyar, Provinsi Bali (Suastika et penyebab penyakit klorosis. Gejala infeksi al. 2012). Pada tahun 1981, tanaman paprika virus yang khas yaitu menguning namun menunjukkan gejala klorosis dengan tulang tulang daun tetap hijau sehingga tampak daun menguning dan daun menggulung menyirip. Gejala ini ditemukan pada tanaman di beberapa daerah di Kitanakagusuku,

\footnotetext{
*Alamat penulis korespondensi: Departemen Proteksi Tanaman, Fakultas Pertanian, Institut Pertanian Bogor, Jalan Kamper, Kampus Darmaga IPB, Bogor 16680

Tel: 0251- 8629364, Faks: 0251- 8629362, Surel: gedesuast@gmail.com
} 
Okinawa, Ishigaki, dan Miyako, Jepang. Gejala ini awalnya diduga disebabkan oleh defisiensi magnesium. Namun, Yonaha et al. (1995) menduga penyakit ini disebabkan oleh infeksi virus. Buah sakit menunjukkan gejala berwarna tidak seragam dan berubah warna (diskolorisasi) pada tanaman paprika di Spanyol (Villanueva et al. 2013).

Berdasarkan pengamatan partikel virus yang diisolasi dari tanaman, partikel virus menyerupai Luteovirus, virus bereplikasi di jaringan floem, dapat ditularkan melalui penyambungan dan vektor Aphis gossypii Glover (Gray dan Gildow 2003; Murakami et al. 2011).

Genom PeVYV (no. aksesi AB594828) berukuran $6244 \mathrm{pb}$ terdiri atas enam open reading frames (ORFs). ORF0 mengkode protein $0(\mathrm{P} 0)$ terdiri atas 249 asam amino, ORF1 dan ORF2 mengkode fusion protein P1-P2 terdiri atas 1085 asam amino, yang diduga berperan sebagai $R N A$-dependent RNA polymerase (RdRp), ORF3 mengkode protein 3 (P3) terdiri atas 206 asam amino yang merupakan coat protein $(\mathrm{CP}$; protein selubung), dan sejajar ORF4 yang mengkode protein 4 (P4) terdiri atas 156 asam amino yang merupakan protein VPg genome linked, dan ORF5 mengkode protein 5 (P5) yang terdiri atas 736 asam amino dan memiliki read-through domain (RTD) terdiri atas produk ORF3 (CP) serta berdekatan dengan ORF5 (NCBI 2013).

RT-PCR tidak efisien untuk deteksi rutin virus dalam skala besar, sehingga metode serologi seperti ELISA masih menjadi pilihan untuk deteksi dini sampel atau monitoring penyakit di lapangan. Produksi antiserum memerlukan antigen dalam jumlah dan kualitas yang cukup. Namun, sangat sulit mendapatkan virus murni dalam jumlah yang cukup pada virus yang distribusinya dalam jaringan tanaman terbatas pada floem dan konsentrasi rendah seperti PeVYV. Berkembangnya teknik biologi molekuler seperti amplifikasi DNA, kloning, dan ekpresi gen pada bakteri ekspresi memungkinkan didapatkan sumber immunogen yang melimpah (Fajardo et al. 2007). Sebelumnya, ekspresi gen CP
Cucumber mosaic virus (CMV) berhasil dikayakan pada bakteri ekspresi $E$. coli galur M15 [pREP4] menggunakan vektor ekspresi pQE30 dan proteinnya digunakan sebagai sumber antigen dalam pembuatan antiserum (Khan et al. 2011). Ekpresi gen CP Rice stripe virus (RSV) berhasil dikayakan pada bakteri E. coli galur BL21(DE3) menggunakan vektor ekspresi pET28 dan pET30 (Lian et al. 2011). Selain itu, ekpresi gen CP Sugarcane streak mosaic virus (SCSMV) berhasil dikayakan pada bakteri E. coli galur BL21(DE3) menggunakan vektor ekspresi pRSET-A (Hema et al. 2003)

Gen protein selubung PeVYV diamplifikasi dengan primer spesifik gen $\mathrm{CP}$ yang mengandung situs enzim restriksi Bam $\mathrm{HI}$ pada primer forward dan PstI pada primer reverse dengan program amplifikasi yang telah dilaporkan sebelumnya (Apindiati et al. 2015). Pita DNA berukuran $\sim 650 \mathrm{pb}$ berhasil teramplifikasi (Gambar 1). Selanjutnya, DNA CP-PeVYV dipotong dengan enzim BamHI dan PstI dan diligasi dengan enzim T4 DNA ligase ke vektor ekspresi pQE30 (Qiagen) pada situs enzim restriksi yang sama sehingga terbentuk plasmid rekombinan pQE30-CPPeVYV dengan ukuran fusi protein $\sim 25 \mathrm{kDa}$ (Gambar 2a).

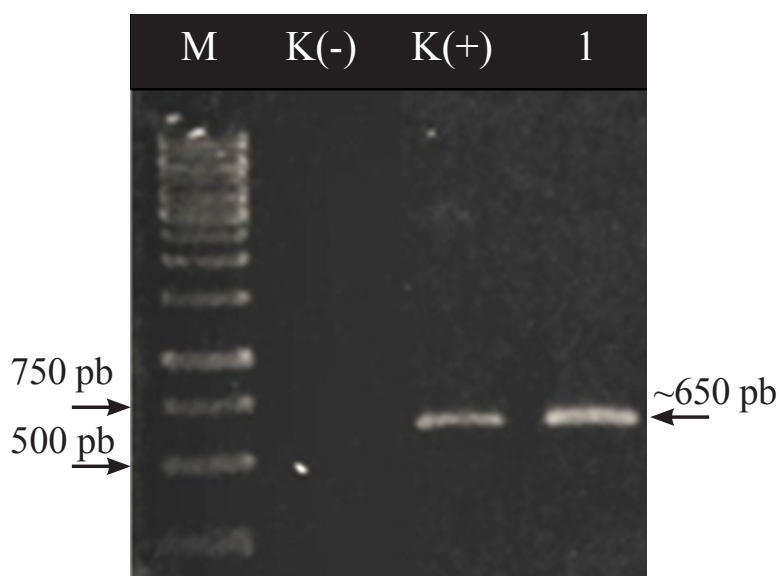

Gambar 1 Hasil amplifikasi DNA sampel daun tanaman cabai bergejala klorosis (lajur 1). $\mathrm{K}(-)$, kontrol sehat; $\mathrm{K}(+)$, kontrol positif dari tanaman sakit dan; M, penanda $1 \mathrm{Kpb}$ DNA ladder (Thermo Scientific, US) (Apindiati et al. 2015). 
Plasmid rekombinan ditransformasi ke $E$. coli galur M15 (Qiagen) dengan metode heat shock dan ditumbuhkan pada media seleksi Luria Bertani Agar (LBA) yang mengandung antibiotik ampisilin $\left(50 \mu \mathrm{g} \quad \mathrm{mL}^{-1}\right)$ dan kanamisin $\left(25 \mu \mathrm{g} \mathrm{mL}^{-1}\right)$. Koloni yang tumbuh pada media seleksi dikonfirmasi dengan PCR koloni menggunakan pasangan primer tersebut di atas.

Ekspresi rekombinan CP-PeVYV dilakukan dengan menginokulasi $500 \mu \mathrm{L}$ bakteri ke dalam $30 \mathrm{~mL}$ media $\mathrm{LB}$ cair yang mengandung antibiotik ampisilin $\left(50 \mu \mathrm{g} \mathrm{mL}^{-1}\right)$ dan kanamisin $\left(25 \mu \mathrm{g} \mathrm{mL}^{-1}\right)$. Optimasi ekspresi rekombinan CP-PeVYV dilakukan pada beberapa suhu inkubasi yang berbeda yaitu suhu $25,28,30$, dan $37{ }^{\circ} \mathrm{C}$ pada konsentrasi Isoprophyl- $\beta$-D-thiogalactoside (IPTG) final $0.25 \mathrm{mM}, 0.5 \mathrm{mM}$, dan $1 \mathrm{mM}$ dan waktu panen $3,6,9,12$, dan 15 jam setelah diinduksi IPTG. Biakan bakteri diinkubasi pada tiap suhu dalam orbital shaker dengan kecepatan $75 \mathrm{rpm}$ hingga pertumbuhan bakteri mencapai $\mathrm{OD}_{600} 0.5$ (sekitar 3-4 jam), lalu diinduksi dengan IPTG dan diinkubasikan kembali agar bakteri mengekspresikan target protein rekombinan. Setelah dipanen, biakan bakteri dipeletkan dengan sentrifugasi pada kecepatan $12000 \mathrm{rpm}$ selama 15 menit. Ekspresi protein yang dihasilkan dalam bentuk insoluble protein pada sel bakteri (pelet) dianalisis pada $12 \%$ sodium dedocyl sulphate polyacrilamide gel electrophoresis (SDS-PAGE).

Gen CP-PeVYV berukuran $\sim 650 \mathrm{pb}$ mengkode $\sim 217$ asam amino (Apindiati et al. 2015). CP-PeVYV 26 kDa (Murakami 2014, komunikasi pribadi). PeVYV memiliki kekerabatan yang dekat dengan Pepper yellow leaf curl polerovirus (PYLCV) (Dombrovsky et al. 2013).

Hasil optimasi ekpresi rekombinan CP-PeVYV pada suhu 25, 28, dan $30{ }^{\circ} \mathrm{C}$ dengan konsentrasi IPTG yang digunakan menunjukkan protein rekombinan CP-PeVYV tidak berhasil terekspresi; pita protein target tidak terbentuk (data tidak ditampilkan). Namun, inkubasi pada suhu $37{ }^{\circ} \mathrm{C}$ protein rekombinan CP menunjukkan terekspresi dengan pita protein berukuran $\sim 25 \mathrm{kDa}$. Di antara konsentrasi IPTG yang digunakan, ekspresi protein rekombinan CP terekspresi pada konsentrasi $0.5 \mathrm{mM}$ dan waktu panen bakteri pada saat 6 jam setelah diinduksi IPTG (Gambar 2b).

Bakteri E. coli memiliki berbagai keunggulan, antara lain ialah kemampuannya untuk tumbuh dengan cepat, densitas sel yang tinggi, media pertumbuhan yang murah, karakteristik genetik yang jelas, serta ketersediaan galur mutan dengan yang sesuai berbagai pasangan vektor kloning. Meskipun tidak selalu ada jaminan bahwa protein heterologus akan dihasilkan oleh $E$. coli dalam jumlah yang tinggi dan aktif secara biologis, berbagai cara telah dilakukan untuk meningkatkan performa dari mikroorganisme ini (Baneyx 1999).

Vektor pQE30 dan bakteri ekspresi M15 adalah termasuk bakteri ekspresi dengan low copy number (Qiagen 2013). Namun, hasil ekspresi protein rekombinan CP-PeVYV menunjukkan masih kurang melimpah. Hal ini menunjukkan perlu optimasi lebih lanjut kondisi ekspresi. Beberapa faktor yang perlu dioptimasi ialah suhu inkubasi yang lebih rendah seperti $20^{\circ} \mathrm{C}$ dengan konsentrasi IPTG kisaran $0.25-1.0 \mathrm{mM}$, jenis bufer lisis protein yang digunakan, dan analisis ekspresi protein pada fraksi cair (soluble/ supernatan).

Berdasarkan hasil tersebut, rekombinan CP-PeVYV berhasil dibuat dan diekspresikan pada bakteri ekspresi. Namun, untuk mendapatkan jumlah protein yang cukup melimpah sebagai imunogen untuk pembuatan antiserum, perlu optimasi lebih lanjut beberapa faktor yang tidak tercakup dalam penelitian ini.

\section{DAFTAR PUSTAKA}

Apindiati RK, Suastika G, Mutaqin KH. 2015. Identifikasi Polerovirus penyebab klorosis pada cabai asal Bali, Indonesia. J Fitopatol Indones. 11(2):43-50. DOI: http://dx.doi. org/10.14692/jfi.11.2.43.

Baneyx F. 1999. Recombinant protein expression in Escherichia coli. Curr Opinion Biotech 10:411-421. DOI: http://dx.doi. org/10.1016/S0958-1669(99)00003-8. 

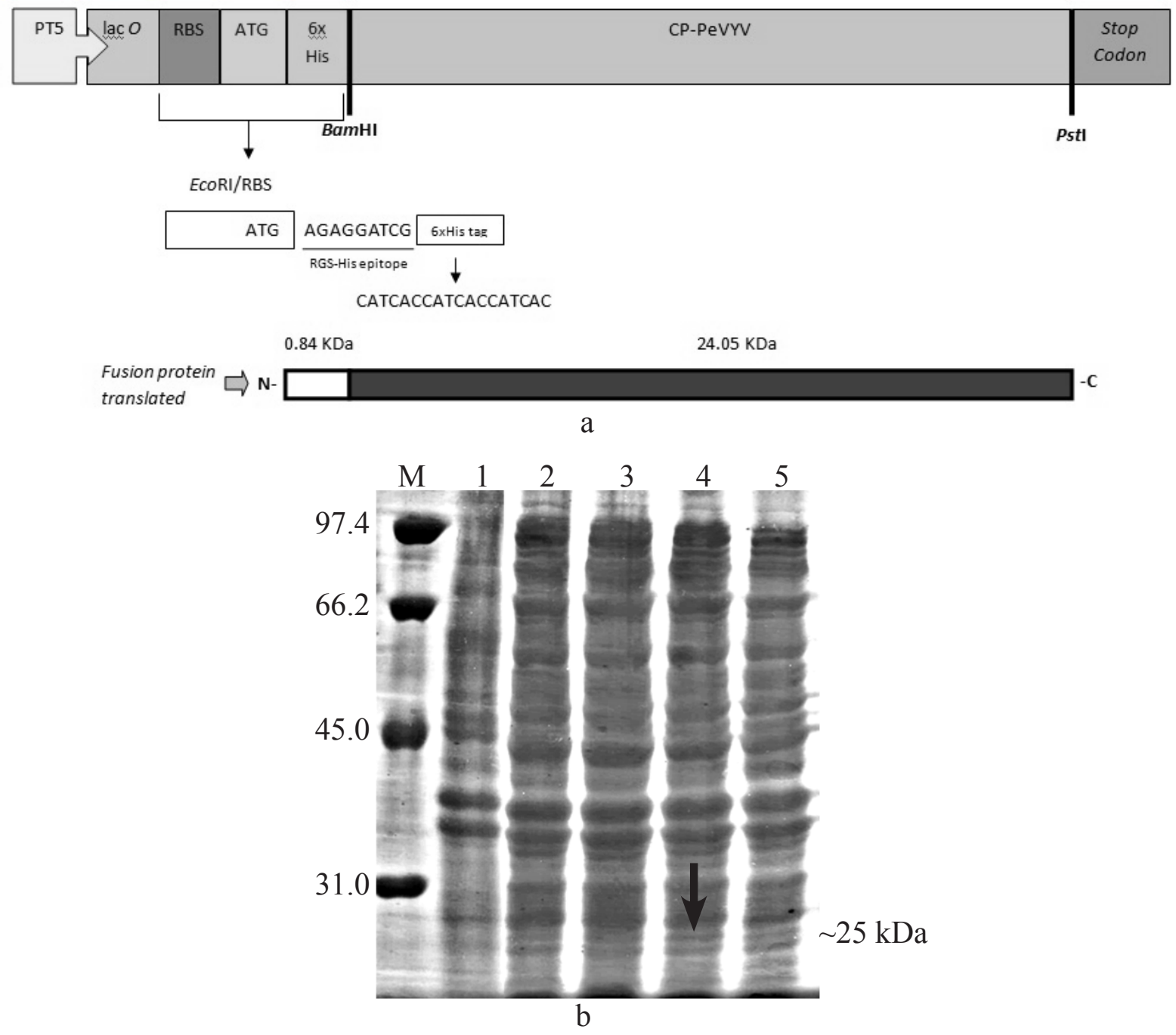

Gambar 2 a, Skematik konstruksi gen CP-PeVYV pada vektor ekspresi pQE30 dengan enzim restriksi BamHI dan Pst I menunjukkan $0.84 \mathrm{kDa} 6 \mathrm{xHistag}$ Protein dan $24.05 \mathrm{kDa}$ fragmen yang terekspresi dari CP-PeVYV; b, Ekspresi gen CP-PeVYV pada SDS-PAGE. Lajur 1, pQE30 tanpa insert; lajur 2, CP rekombinan tidak diinduksi; lajur 3-5 diinduksi IPTG $0.25 \mathrm{mM}, 0.5$ $\mathrm{mM}$, dan $1 \mathrm{mM}$; MW, berat molekul protein $(\mathrm{kDa})$. Penanda protein SDS-PAGE Low Range dengan ukuran $\mathrm{kDa}(\mathrm{BioRad})$.

Dombrovsky A, Glanz E, Lachman O, Sela N, Doron-Faigenboim A, Antignus Y. 2013. The complete genomic sequence of Pepper yellow leaf curl virus (PYLCV) and its implications for our understanding of evolution dynamics in the genus Polerovirus. Plos One. 8(7):1-11(e70722). DOI: http://dx.doi.org/10.1371/journal. pone. 0070722 .

Fajardo TVM, Barros DR, Nickel O, Kuhn GB, Zerbini FM. 2007. Expression of Grapevine leafroll-associated virus 3 coat protein gene in Escherichia coli and production of polyclonal antibodies. Fitopatol Brasil. 32:496-500. DOI: http://dx.doi.org/10.1590/S010041582007000600007

Gray S, Gildow FE. 2003. Luteovirus-aphid interactions. Annu Rev Phytopathol. 41:539-66.DOI:http://dx.doi.org/10.1146/ annurev.phyto.41.012203.105815.

Hema M, Kirthi N, Sreenivasulu P, Savithri HS. 2003. Development of recombinant coat protein antibody based IC-RT-PCR for detection and discrimination of Sugarcane streak mosaic virus isolates from Southern 
India. Arch Virol. 148:1185-1193. DOI: http://dx.doi.org/10.1007/s00705-0030015-y.

Khan S, Jan AT, Mandal B, Haq QMR. 2011. Immunodiagnostics of Cucumber mosaic virus using antisera developed against recombinant coat protein. Arch Phytopathol and Plant Protection. 45(5):561-569. DOI: http://dx.doi.org/10.1080/03235408.2011. 588043.

Lian S, Jonson MG, ChoWK, Choi HS, Je YH, Kim KH. 2011. Generation of antibodies against Rice stripe virus proteins based on recombinant protein and synthetic polypeptides. Plant Pathol J. 27(1):37-43. DOI: http://dx.doi.org/10.5423/ PPJ.2011.27.1.037.

Murakami R, Nakashima N, Hinomoto N, Kawano S, Toyosato T. 2011. The genome sequence of Pepper vein yellows virus (family Luteoviridae, genus Polerovirus). Arch Virol. 156:921-923. DOI: http:// dx.doi.org/10.1007/s00705-011-0956-5.

[NCBI] National Center for Biotechnology Information. 2013. Pepper vein yellows virus genomic RNA, complete genome. Bethesda MD (USA): Nucleotide. http://www.ncbi.nlm.nih.gov/nuccore/ AB594828.1 [diakses 5 Juli 2015].

Qiagen. 2013. Growth of Bacterial Cultures. https://www.qiagen.com/id/resources/ technologies/plasmid-resource-center/ growth $\% 20$ of $\% 20$ bacterial $\% 20$ cultures/ [diakses 2015 Juli 5].

Suastika G, Hartono S, Nyana IDN, Natsuaki T. 2012. Laporan pertama tentang infeksi Polerovirus pada tanaman cabai di daerah Bali, Indonesia. J Fitopatol Indones. 8(5): 151-154.DOI: http://dx.doi.org/10.14692/ jfi.8.5.151.

Villanueva F, Castillo P, Font MI, Fernandez AA, Moriones E, Castillo JN. 2013. First Report of Pepper vein yellows virus Infecting Sweet Pepper in Spain. American Phytopathol Soc. 97(9):1261. DOI: http:// dx.doi.org/10.1094/PDIS-04-13-0369PDN.

Yonaha T, Toyosato T, Kawano S, Osaki T. 1995. Pepper vein yellows virus, a Novel Luteovirus from Bell Pepper Plants in Japan. Ann Phytopathol Soc Jpn. 61: 178-184. DOI: http://dx.doi.org/10.3186/ jjphytopath.61.178. 